\title{
Blood pressures, heart rate and locomotor activity during salt loading and angiotensin II infusion in protease-activated receptor 2 (PAR $\mathbf{P}_{2}$ knockout mice
} John J McGuire*, Bruce N Van Vliet and Sarah J Halfyard

\author{
Address: Cardiovascular Research Group, Division of BioMedical Sciences, Faculty of Medicine, Memorial University, St. John's, Newfoundland, \\ Canada \\ Email: John J McGuire* - mcguire@mun.ca; Bruce N Van Vliet - vanvliet@mun.ca; Sarah J Halfyard - sarahhalfyard@hotmail.com \\ * Corresponding author
}

Published: 21 October 2008

BMC Physiology 2008, 8:20 doi:10.1 186/1472-6793-8-20
Received: I August 2008

Accepted: 21 October 2008

This article is available from: http://www.biomedcentral.com/1472-6793/8/20

(C) 2008 McGuire et al; licensee BioMed Central Ltd.

This is an Open Access article distributed under the terms of the Creative Commons Attribution License (http://creativecommons.org/licenses/by/2.0), which permits unrestricted use, distribution, and reproduction in any medium, provided the original work is properly cited.

\begin{abstract}
Background: In this study we used radiotelemetry to measure hemodynamic variables and locomotor activity in conscious unrestrained male Protease-Activated Receptor 2 (PAR-2) knockout mice in order to provide a detailed assessment of their blood pressure phenotype. In addition we tested for an influence of PAR- 2 on salt-sensitivity $(8 \%$ versus $0.5 \% \mathrm{NaCl}$ diet, 2.5 weeks) and angiotensin II-induced hypertension (I $\mu \mathrm{g} \mathrm{Ile}$-angiotensin $\mathrm{II} / \mathrm{kg} / \mathrm{min}$ versus $0.25 \mu \mathrm{l} / \mathrm{h}$ saline, 2 weeks).

Results: Systolic arterial pressures of PAR-2 $-/-(129 \pm I \mathrm{mmHg}, n=2 \mathrm{I}, \mathrm{P}<0.05)$ were statistically higher than those of C57BL/6) ( $124 \pm \mathrm{I} \mathrm{mmHg}, \mathrm{n}=33)$ throughout the $24 \mathrm{~h}$ period under baseline conditions. Pulse pressures in PAR-2 -/- were also significantly elevated $(33 \pm \mathrm{I} \mathrm{mmHg}$ versus $30 \pm$ $\mathrm{I} \mathrm{mmHg}, \mathrm{P}<0.05$ ), whereas diastolic arterial pressures were not. Heart rates in PAR-2 -/- were not significantly different than controls, with the exception that heart rate of PAR-2 -/- was 23 beats per min higher than controls $(P<0.00 \mathrm{I})$ during periods of nocturnal activity. The diurnal pattern and intensity of locomotor activity were not found to differ between strains. A high salt diet led to increased blood pressures, decreased heart rates, increased time spent active and decreased intensity levels of locomotor activity. Salt-induced changes in systolic and pulse pressures in PAR2 -/- were less than in C57B/6). Angiotensin II treatment increased pressures, decreased heart rates, decreased time spent active and decreased intensity levels of activity of PAR-2 -/-, all to the same extent as C57BL/6]. A trend of lower blood pressures during the middle period of angiotensin II treatment period was observed in individual PAR-2 -/-.
\end{abstract}

Conclusion: The data indicated gene knockout of PAR-2 was associated with a modest change in blood pressure phenotype. PAR-2 -/- mice exhibited moderate elevation of systolic arterial and pulse pressures, yet no increased diastolic arterial pressure, no increased blood pressure responses to high salt diet and a subtle difference in the time course of the blood pressure responses to angiotensin II infusion. 


\section{Background}

Protease-activated receptor $2\left(\mathrm{PAR}_{2}\right)$, a 7 transmembrane domain $\mathrm{G}$ protein coupled receptor, has been found to be activated endogenously by specific serine proteases $[1,2]$. Supposedly, rather than by the binding of any known soluble ligands in the circulation, serine proteases released by endothelial cells and other cells during inflammation and/or injury initiates $\mathrm{PAR}_{2}$-dependent actions that range from endothelial-dependent vasodilation to production of cytokines and stimulated de novo expression of adhesion molecules [3]. No obvious blood pressure phenotypes have been reported in $\mathrm{PAR}_{2}-/$ - albeit such in vivo observations have so far been limited to anaesthetized mice [4]. Studies have reported $\mathrm{PAR}_{2} / /$ - mice were resistant to induction of inflammatory disease models including arthritis [5,6], colitis [7], airway inflammation [8], and vascular acute inflammation $[9,10]$ and renal inflammation [11]. On the other hand, $\mathrm{PAR}_{2}-/$ - were more susceptible to neurodegenerative inflammation $[12,13]$ and focal brain ischemia [14]. Still in other studies, $\mathrm{PAR}_{2}-/$ were no less or more affected than normal mice subjected to endotoxemia [15] and renal ischemia reperfusion injury [16]. To date there have been no studies in vivo using $\mathrm{PAR}_{2}$-/- whereby their constitutive hemodynamics have been challenged such as in mouse models of acquired hypertension. High salt diet feeding [17] and angiotensin II infusions $[18,19]$ can reveal novel pathophysiological interactions of receptor signaling on hemodynamic control of blood pressure. Serine proteinase activities (renal kallikreins in particular) have been linked to salt-sensitivity [20-22] and both salt- and angiotensin II-induced hypertension have been linked separately to pro-inflammation signalling pathways such as nuclear factor- $\kappa B$ shared in common with $\mathrm{PAR}_{2}$ [23-30]. Such findings provided a good rationale for testing the pathophysiological interactions of $\mathrm{PAR}_{2}$ with regulation of blood pressure during altered hemodynamic states particularly with the development of acquired hypertension.

The goals of this study were to describe the blood pressure phenotype of conscious $\mathrm{PAR}_{2}-/$ - using radiotelemetry. Specifically, we aimed to determine the baseline blood pressure level of $\mathrm{PAR}_{2}-/-$, and whether $\mathrm{PAR}_{2}-/$ - were more salt-sensitive and/or more responsive to infusion with angiotensin II than controls. These data were expected to inform us about the interaction of $\mathrm{PAR}_{2}$ with blood pressure regulation and provide insight into therapeutic possibilities for $\mathrm{PAR}_{2}$-targetted drugs in the future.

\section{Methods \\ Ethics}

All protocols were approved by the Institutional Animal Care Committee of Memorial University in accordance with the guidelines and principles recommended for the use of animals in research by the Canadian Animal Care Council.

\section{Animals}

Control mice $\left(\mathrm{PAR}_{2}+/+; \mathrm{C} 57 \mathrm{BL} / 6 \mathrm{~J}\right)$ and $\mathrm{PAR}_{2}$-deficient mice $\left(\mathrm{PAR}_{2}-/-; \mathrm{B} 6 . \mathrm{Cg}-\mathrm{F} 2 \mathrm{rll} \mathrm{\textrm {tm }} 1 \mathrm{mslb} / \mathrm{J}\right)$ were purchased from the Jackson Laboratories (Bar Harbor, ME). Except during high-salt (HS) diet feeding, mice were fed a standard regular-salt (RS) feed containing $0.28 \%$ sodium $(0.5 \%$ $\mathrm{NaCl}), 1 \%$ calcium, $0.59 \%$ potassium and $0.93 \%$ phosphorus (NIH-31 autoclavable open formula mouse diet; Zeigler Bros Inc., PA). High-salt diet containing $8 \% \mathrm{NaCl}$ was comprised otherwise as above (Zeigler Bros Inc., PA). Mice were provided water ad libitum. Mice were housed individually in air filter-topped cages in a room of the Animal Care Facility of the Health Sciences Center dedicated to recording radiotelemetry data. The room lighting was set to a $12 \mathrm{~h}$ light and $12 \mathrm{~h}$ dark cycle and room temperature was $20-22^{\circ} \mathrm{C}$.

\section{Experimental Protocol}

Mice (males; $\mathrm{PAR}_{2}+/+$ : 10-20 weeks of age, 25-30 g; $\mathrm{PAR}_{2}$ -/-: 10-30 weeks of age, 24-30 g) were implanted with a telemeter (TA11PA-C10, Datasciences Inc.) via the right carotid artery $[31,32]$ under isoflurane/oxygen anaesthesia. All mice were allowed to recover from these surgeries for 13 to 18 days prior to recording their baseline variables. For the HS challenge protocol, the BP data were recorded by telemetry continuously for 3-9 days at baseline and then for 18 days following the switch to experimental diet ( $5 \mathrm{PAR}_{2}+/+$ and $5 \mathrm{PAR}_{2}-/-$ ). For the protocol comparing the effect of high Ang II in each strain, baseline recordings were made for a 4-7 day period. On Day 0 of the Ang II infusion protocol, mice were removed from their rooms shortly after the start of the light period and a micro-osmotic pump (ALZET model 1002) containing either isotonic saline (13 $\mathrm{PAR}_{2}+/+$ and $\left.7 \mathrm{PAR}_{2}-/-\right)$ or Ang II (15 $\mathrm{PAR}_{2}+/+$ and $9 \mathrm{PAR}_{2}-/-; 1 \mu \mathrm{g} \mathrm{Ile}^{5}$-angiotensin $/ \mathrm{kg} /$ min) was implanted dorsally s.c. Pump implantation ( 10-15 $\mathrm{min}$ ) was performed using isoflurane/oxygen anaesthesia, followed by monitoring their recovery for 4$6 \mathrm{~h}$ before being returned to their home cages. BP data sampling was then restarted $\sim 18 \mathrm{~h}$ later at the start of the next light period (day 1). According to the manufacturer's literature provided with the product, steady state rate of infusion was expected to be reached $12 \mathrm{~h}$ after implant of micro-osmotic pumps. BP data in saline-treated and Ang II-treated mice were recorded for 12-13 days before being sacrificed. The proper placement of the catheter tips of telemeters in the aortic arch were confirmed at autopsy.

\section{Telemetry}

Hemodynamic (systolic arterial pressure (SAP), diastolic arterial pressure (DAP), heart rate (HR)) and locomotor activity data were sampled for $3 \mathrm{~s}$ at $30 \mathrm{~s}$ intervals [32]. 
The $24 \mathrm{~h}$ data sets were processed using an Excel spreadsheet application designed for this purpose [33]. Data representing the inactive state for each mouse was defined by locomotor activity signal (Act, in arbitrary units) equal to 0 and active state was defined by Act $>0$. Intensity of the continuous activity (Act intensity) was calculated by logarithmic base 10 transformation of all Act values when Act $>0$. Corrections for calibration drift were applied to data using the external pressure calibrations made at the end of the protocol $[17,32]$. Unexpected electrical power failures led to data exclusion and uneven sample sizes on several days of the experiment. Data recorded during cage change days (every 7 days) and day 0 of pump implants have been excluded. Only data sets from mice characterized by a stable $24 \mathrm{~h}$ MAP during the baseline recording period and pulse pressure $(\mathrm{PP}) \geq 20 \mathrm{mmHg}$ throughout the day were included in analyses. This criterion resulted in exclusion of telemeter data from $1 \mathrm{PAR}_{2}+/+$ and $4 \mathrm{PAR}_{2}$-/-. Regardless of the PP exclusion criterion, the recordings from these mice typically contained data points at both extremely high and low implausible ranges as well as periods of missing data acquisition signals, which have become characteristics used to identify artifacts in telemetry data.

\section{Data Analyses}

Values reported and symbols on graphs are the means \pm standard error of the mean. For overall characterization of phenotype, the data obtained at baseline preceding both experimental protocols (high salt feeding and microosmotic pump implants) were combined for each strain. Linear regression analysis indicated that age did not have an effect on baseline blood pressures or the effects of the experimental protocols in our study. The calculations of difference in telemetry variables during the experimental treatments are paired to the average value of the individual mouse's baseline recordings. There are 6 parts to the presentation of statistical analyses: 1) Comparison of the effect of strain on $12 \mathrm{~h}$ light and $12 \mathrm{~h}$ dark telemetry vari- ables at baseline (2 way ANOVA). 2) Comparison of the effect of strain on $12 \mathrm{~h}$ light and $12 \mathrm{~h}$ dark variables at baseline with matching of variables to activity level (Act = 0 or Act $>0$; 2 way repeated measures ANOVA). 3) Comparison of the effect of strain on change in variables during HS diet (2 way repeated measures ANOVA). 4) Comparison of the effect of treatment (high salt vs normal salt) on variables with time (2 way repeated measures ANOVA). 5) Comparison of the effect of strain on change in variables during micro-osmotic pump treatments (2 way ANOVA). 6) Comparison of the effect of microosmotic pump treatment on variables (2 way ANOVA). Bonferroni post-hoc testing was used to identify differences between specific groups in the multiple comparisons. $P<0.05$ was considered significant.

\section{Results \\ Baseline hemodynamics of $P A R_{2}$-/- and $P A R_{2}+/+$ mice}

Blood pressures were modestly, but significantly $(P<$ 0.05) higher in $\mathrm{PAR}_{2}$-/- than $\mathrm{PAR}_{2}+/+$ mice (Figure 1, Table 1). During the baseline period, SAP and pulse pressures (PP) of $\mathrm{PAR}_{2}$-/- were 3-4\% and 6-10\% higher, respectively, than those of $\mathrm{PAR}_{2}+/+$ for both $12 \mathrm{~h}$ dark and $12 \mathrm{~h}$ light periods. These differences between strains were independent of locomotor activity, being persistent during periods of both activity and inactivity (Table 2). In both strains, periods of locomotor activity were associated with higher blood pressures $(12 \mathrm{~h}$ light: $\Delta \mathrm{SAP}=19$ $\mathrm{mmHg}, \Delta \mathrm{DAP}=17 \mathrm{mmHg} ; 12 \mathrm{~h}$ dark: $\Delta \mathrm{SAP}=13 \mathrm{mmHg}$, $\Delta \mathrm{DAP}=10 \mathrm{mmHg}$ ) (Table $2 ; P<0.001)$. Differences in diastolic pressures and HR between $\mathrm{PAR}_{2}$-/- and $\mathrm{PAR}_{2}+$ /+ were generally slight and, with one exception (active HR in dark period, $\mathrm{P}<0.01$ ) multiple comparisons between strains were not statistically significant (Table 2). Patterns of locomotor activity and the intensity level of activity during the light and dark periods also did not differ between strains (Figure 1, Table 2).

Table I: Summary of baseline hemodynamics of PAR $_{2} /-$ and PAR $_{2}+/+$ mice.

\begin{tabular}{|c|c|c|c|c|c|}
\hline Time Period & Variable & PAR $_{2}+/+$ & & PAR $_{2}-/-$ & Ratio $\mathrm{PAR}_{2}-/-$ to $\mathrm{PAR}_{2}+/+$ \\
\hline \multirow[t]{4}{*}{ I h dark } & $\mathrm{SAP}(\mathrm{mmHg})$ & $|3| \pm 1$ & $* *$ & $136 \pm 1$ & 1.04 \\
\hline & $\mathrm{DAP}(\mathrm{mmHg})$ & $101 \pm 1$ & & $102 \pm 1$ & 1.00 \\
\hline & $\mathrm{PP}(\mathrm{mmHg})$ & $31 \pm 1$ & $*$ & $33 \pm 1$ & 1.06 \\
\hline & HR (beats min-1) & $607 \pm 6$ & & $622 \pm 5$ & 1.02 \\
\hline \multirow[t]{4}{*}{ I 2 h light } & $\mathrm{SAP}(\mathrm{mmHg})$ & $118 \pm 1$ & $*$ & $122 \pm 1$ & 1.03 \\
\hline & $\mathrm{DAP}(\mathrm{mmHg})$ & $89 \pm 1$ & & $89 \pm 1$ & 1.00 \\
\hline & $\mathrm{PP}(\mathrm{mmHg})$ & $29 \pm 1$ & $*$ & $32 \pm 1$ & 1.10 \\
\hline & HR (beats min-1) & $587 \pm 4$ & & $595 \pm 5$ & 1.01 \\
\hline
\end{tabular}

Telemetry data from 12 hour light and 12 hour dark periods were obtained from $33 \mathrm{PAR}_{2}+/+$ and $2 \mathrm{I} \mathrm{PAR}_{2}-/-$ mice. Values are mean \pm standard error of mean. $P$ values determined by multiple comparisons testing between strains during light and dark periods using 2 way ANOVA and Bonferroni post-hoc. $*, P<0.05 ; * *, P<0.01$. 
Table 2: Activity effects on hemodynamics of $\mathrm{PAR}_{2}-/-$ and $\mathrm{PAR}_{2}+/+$ mice.

\begin{tabular}{|c|c|c|c|c|c|}
\hline Time Period & Variable & PAR $_{2}+/+$ & & $\mathbf{P A R}_{2}=/-$ & Ratio PAR $_{2}-/-$ to PAR $_{2}+/+$ \\
\hline \multirow[t]{10}{*}{ I2 h dark } & $\%$ time active & $52 \pm 1$ & & $49 \pm 2$ & 0.96 \\
\hline & Act intensity & $1.15 \pm 0.01$ & & $1.17 \pm 0.02$ & 1.02 \\
\hline & SAP inactive $(\mathrm{mmHg})$ & $125 \pm 1$ & $*$ & $128 \pm 1$ & 1.02 \\
\hline & SAP active $(\mathrm{mmHg})$ & $137 \pm 1$ & $* * *$ & $142 \pm 1$ & 1.04 \\
\hline & DAP inactive $(\mathrm{mmHg})$ & $95 \pm 1$ & & $96 \pm 1$ & 1.01 \\
\hline & DAP active $(\mathrm{mmHg})$ & $106 \pm 1$ & & $109 \pm 1$ & 1.03 \\
\hline & PP inactive $(\mathrm{mmHg})$ & $29 \pm 1$ & $*$ & $33 \pm 1$ & 1.14 \\
\hline & PP active $(\mathrm{mmHg})$ & $31 \pm 1$ & $*$ & $34 \pm 1$ & 1.10 \\
\hline & HR inactive (beats $\mathrm{min}^{-1}$ ) & $572 \pm 6$ & & $581 \pm 5$ & 1.02 \\
\hline & HR active (beats min $^{-1}$ ) & $640 \pm 6$ & $* *$ & $663 \pm 6$ & 1.04 \\
\hline \multirow[t]{10}{*}{ I 2 h light } & $\%$ time active & $28 \pm 1$ & & $26 \pm 1$ & 0.93 \\
\hline & Act intensity & $1.01 \pm 0.02$ & & $0.98 \pm 0.02$ & 0.97 \\
\hline & SAP inactive $(\mathrm{mmHg})$ & $112 \pm 1$ & $*$ & $117 \pm 1$ & 1.04 \\
\hline & SAP active $(\mathrm{mmHg})$ & $|3| \pm 1$ & $* *$ & $136 \pm 1$ & 1.04 \\
\hline & DAP inactive $(\mathrm{mmHg})$ & $84 \pm 1$ & & $85 \pm 1$ & 1.01 \\
\hline & DAP active $(\mathrm{mmHg})$ & $100 \pm 1$ & & $102 \pm 1$ & 1.02 \\
\hline & $\mathrm{PP}$ inactive $(\mathrm{mmHg})$ & $28 \pm 1$ & $*$ & $32 \pm 1$ & 1.14 \\
\hline & $\mathrm{PP}$ active $(\mathrm{mmHg})$ & $31 \pm 1$ & $*$ & $34 \pm 1$ & 1.10 \\
\hline & HR inactive (beats $\mathrm{min}^{-1}$ ) & $543 \pm 4$ & & $544 \pm 6$ & 1.00 \\
\hline & HR active (beats $\min ^{-1}$ ) & $628 \pm 4$ & & $634 \pm 5$ & 1.01 \\
\hline
\end{tabular}

Telemetry data from 12 hour light and 12 hour dark periods were obtained from $33 \mathrm{PAR}_{2}+/+$ and $2 \mathrm{I} \mathrm{PAR}_{2}-/$ - mice. Hemodynamic data were matched to locomotor activity status. Values are mean \pm standard error of means. $P$ values determined by multiple comparisons testing between strains during light and dark periods using 2 way ANOVA and Bonferroni post-hoc. *, $P<0.05$; **, $P<0.01$; ***, $P<0.001$.

\section{Salt sensitivity of PAR $_{2}-/$ - versus PAR $_{2}+/+$}

Both dark and light period BP were increased by 3-10 mmHg by the high salt diet in both $\mathrm{PAR}_{2}-/$ and $\mathrm{PAR}_{2}+/+$ mice relative to the normal salt diet period (Figure 2 and Figure 3). 2 way ANOVA indicated a statistically significant effect of strain on elevation of SAP $(P<0.05)$ irrespective of night or day during the HS diet, but differences for specific time points were not resolved by Bonferroni post-hoc tests. However, in contrast to our initial hypothesis, the elevation of SAP by HS was less in $\mathrm{PAR}_{2}-/$ - than in $\mathrm{PAR}_{2}+/+$. The elevation of DAP by HS diet was not different between the strains. $12 \mathrm{~h}$ dark period pressures remained elevated throughout the treatment period (Figure 2). In contrast, the $12 \mathrm{~h}$ light period pressures peaked on the first few days of high salt and then returned to baseline (Figure 3). Consistent with the finding of an effect of strain on systolic, but not on diastolic pressures, 2 way ANOVA indicated a significant effect of strain on the elevation of PP by the HS diet $(\mathrm{P}<0.05)$ during both night and day, the salt-induced changes in PP being less in $\mathrm{PAR}_{2}$ -/- than in $\mathrm{PAR}_{2}+/+$. We observed small 1-3 mmHg elevations of pulse pressures in $\mathrm{PAR}_{2}+/+$ until day 13 of high salt diet. A significant ( $3 \mathrm{mmHg}$ ) difference between strains was resolved by Bonferroni post-hoc for the $12 \mathrm{~h}$ light PP difference on day 12 (Figure 3). Both strains also exhibited similar decreased heart rates that plateaued at $\sim 60$ beats $\mathrm{min}^{-1}$ below the RS diet period around day 13 of high salt diet.

\section{Angiotensin II effects on hemodynamics of $P A R_{2} / /$ and PAR $_{2}+/+$}

Angiotensin II infusion had relatively similar effects on BP in $\mathrm{PAR}_{2}-/-$ and $\mathrm{PAR}_{2}+/+$, with systolic and diastolic pressures increasing by $20-55 \mathrm{mmHg}$ over the $12 \mathrm{~d}$ infusion period (Figure 4 and 5). The interaction of time and treatment was significant for BP variables ( 2 way ANOVA $P<$ $0.05)$. In both strains, the rise in BP tended to be biphasic, with an initial peak on days 1-4 being followed by a dip in $\mathrm{BP}$ before it again rose during the final days of the infusion. The intensity of the BP dip tended to be greater in $\mathrm{PAR}_{2}$-/- mice, and this effect reached significance for all indices of BP recorded on the $7^{\text {th }}$ day of infusion. However, the initial and final BP levels produced by Ang II infusion did not differ between strains. Ang II infusion also led to a progressive increase in PP which tended to be greater in $\mathrm{PAR}_{2}$-/- mice, an effect that reached statistical significance for data obtained during the $12 \mathrm{~h}$ dark period (Figure 4).

Ang II infusion was associated with similar transient reductions in HR, Act intensity and \% time spent active in both strains. We did not observe any effect of microosmotic pumps containing saline on the variables of either strain of mouse relative to the baseline period (Figure 4 and Figure 5). 
systolic arterial pressure

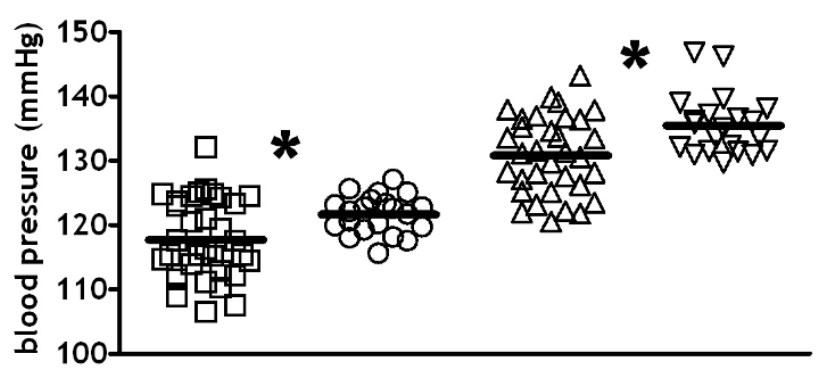

diastolic arterial pressure

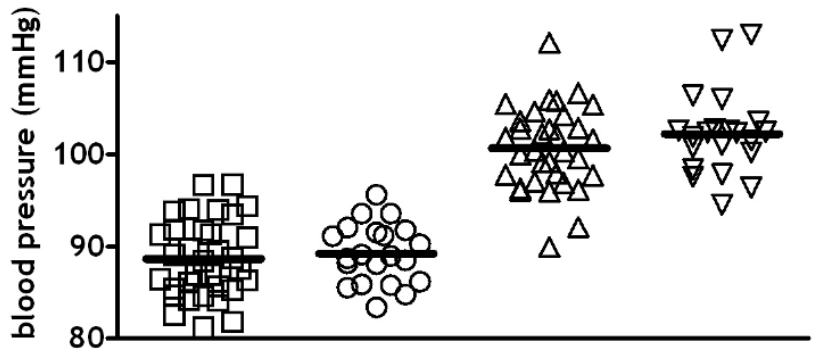

pulse pressure pressure

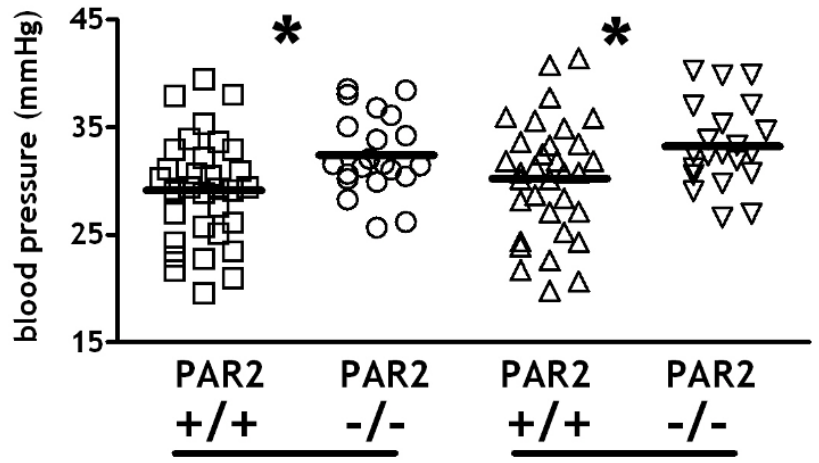

$12 \mathrm{~h}$ light period $12 \mathrm{~h}$ dark period heart rate

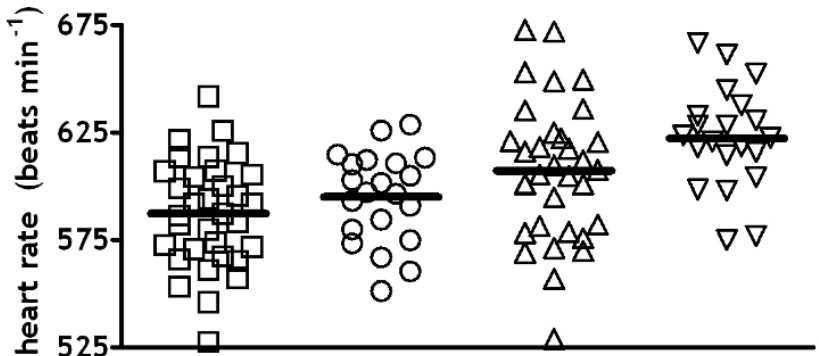

locomotor activity intensity

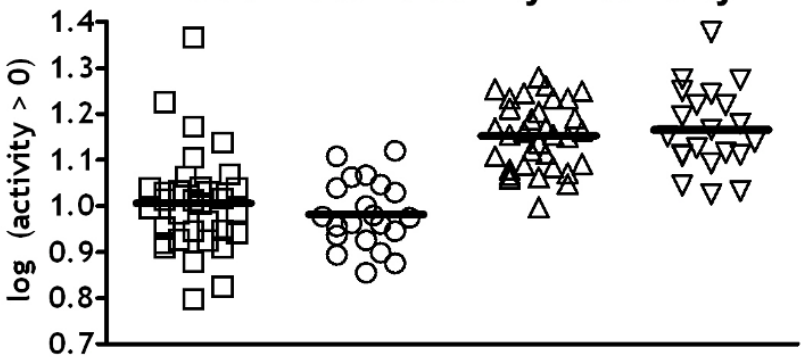

$\%$ time spent active

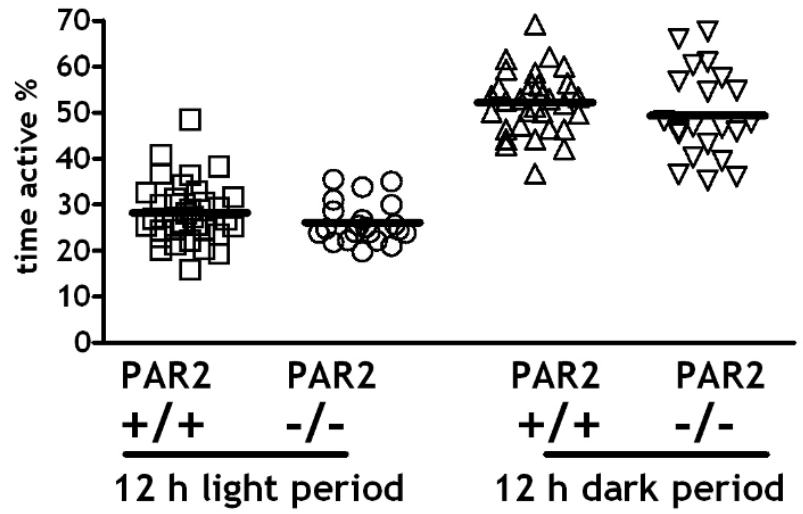

Figure I

Hemodynamics and locomotor activity in $\mathbf{P A R _ { 2 }}-/-$ and $\mathbf{P A R _ { 2 }}+/+$. Symbols are the means of variables from the $12 \mathrm{~h}$ light and $\mathrm{I} 2 \mathrm{~h}$ dark periods in individual mice recorded via radiotelemetry during baseline periods of 2 days. The mean of each strain is indicated by a horizontal bar. $n=2$ PAR $_{2}-/$ - and $33 \mathrm{PAR}_{2}+/+$. $* \mathrm{P}<0.05, \mathrm{PAR}_{2}+/+$ compared to $\mathrm{PAR}_{2}-/-$ using 2 way repeated measures ANOVA and Bonferroni post-hoc.

\section{Discussion}

The main findings from our study were that gene knockout of $\mathrm{PAR}_{2}$ was associated with only a modest change in blood pressure phenotype. PAR-2 mice exhibited moderate elevation of systolic arterial and pulse pressures, yet no increase of diastolic arterial pressure, no increased responses to salt and only a subtle difference on the time course of the blood pressure responses to Ang II infusion.
We found small yet significant increases in blood pressures of $\mathrm{PAR}_{2}$-/- mice which led us to conclude their phenotype is characterized by moderate elevation in systolic arterial and pulse pressures, but not diastolic arterial pressures. Our telemetry data comparisons of $\mathrm{PAR}_{2}$-/- to the background genetic controls $(\mathrm{C} 57 \mathrm{BL} / 6 \mathrm{~J})$ provide the first description of blood pressures and heart rates in conscious $\mathrm{PAR}_{2}$-/-. Previously it was reported that the acute hemodynamics (i.e. heart rates, blood pressures) of $\mathrm{PAR}_{2}$ -/- were not different than controls based on intracarotid 


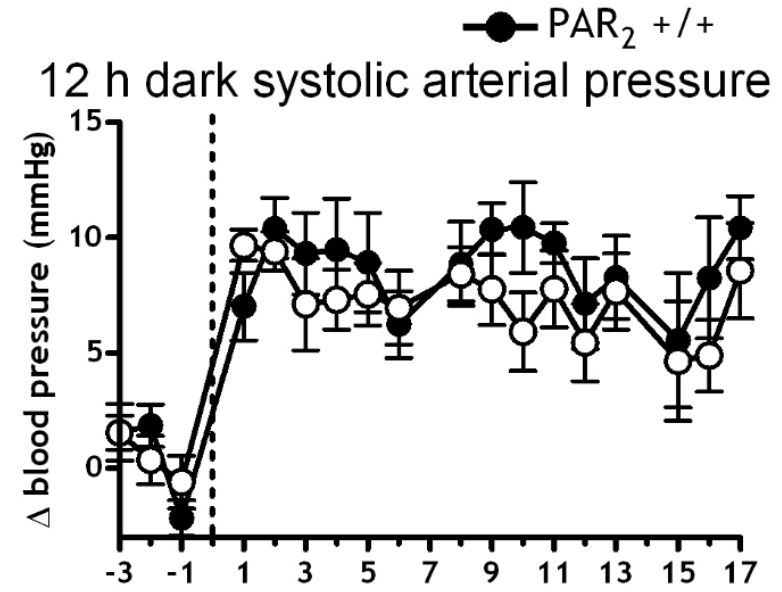

$$
\text { -O- } \mathrm{PAR}_{2}-/
$$

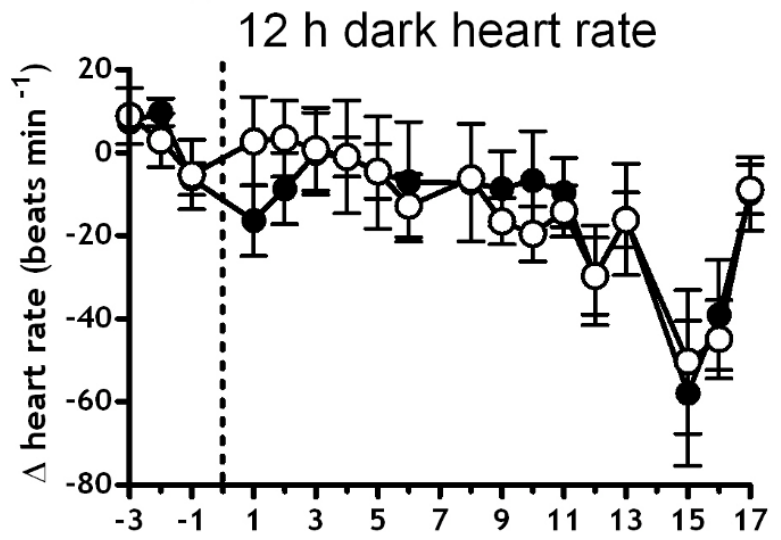

$12 \mathrm{~h}$ dark diastolic arterial pressure

$12 \mathrm{~h}$ dark locomotor activity intensity
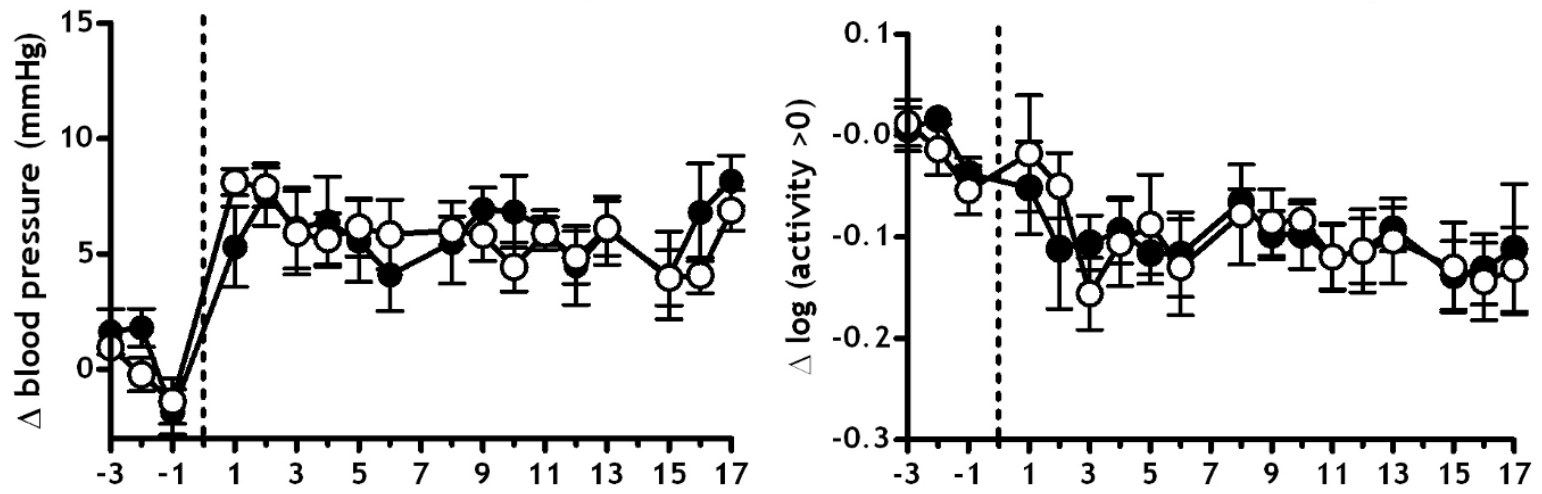

12 h dark pulse pressure

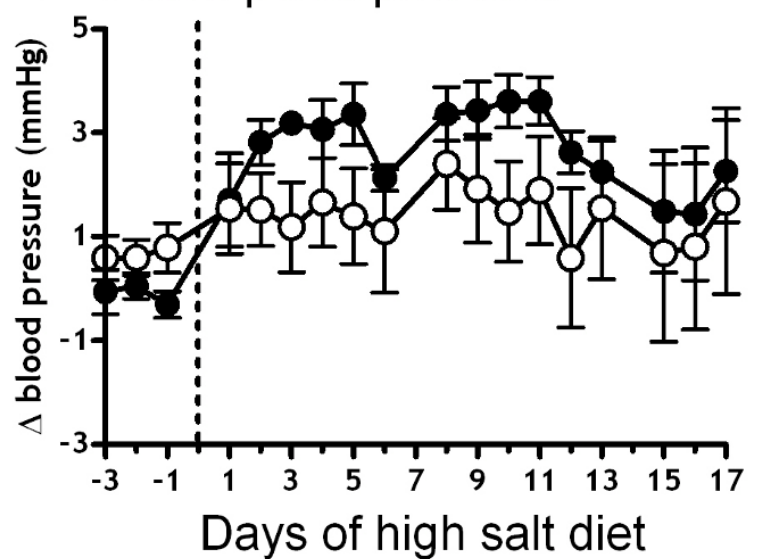

$12 \mathrm{~h}$ dark \% time spent active

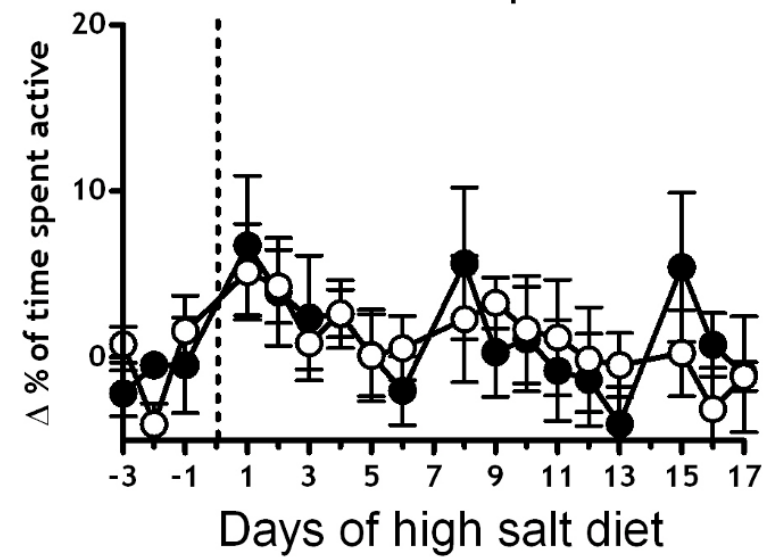

Figure 2

Effect of high salt-diet feeding on PAR $_{2}$-/- versus $\mathbf{P A R}_{\mathbf{2}}+/+$ hemodynamics and locomotor activity during $\mathbf{I} \mathbf{h}$ dark periods. Variables were measured every $30 \mathrm{~s}$ for 18 days via radiotelemetry during a high salt diet $(8 \% \mathrm{NaCl})$ ad libitium. Symbols represent the change in means of variables over the $12 \mathrm{~h}$ dark periods relative to baseline feeding with a normal salt $\operatorname{diet}(0.4 \% \mathrm{NaCl}) . \mathrm{n}=5$ in each strain. 2 way repeated measures ANOVA indicated a significant difference $(P<0.05)$ for systolic and pulse pressures between $\mathrm{PAR}_{2}-/$ - and $\mathrm{PAR}_{2}+/+$. 

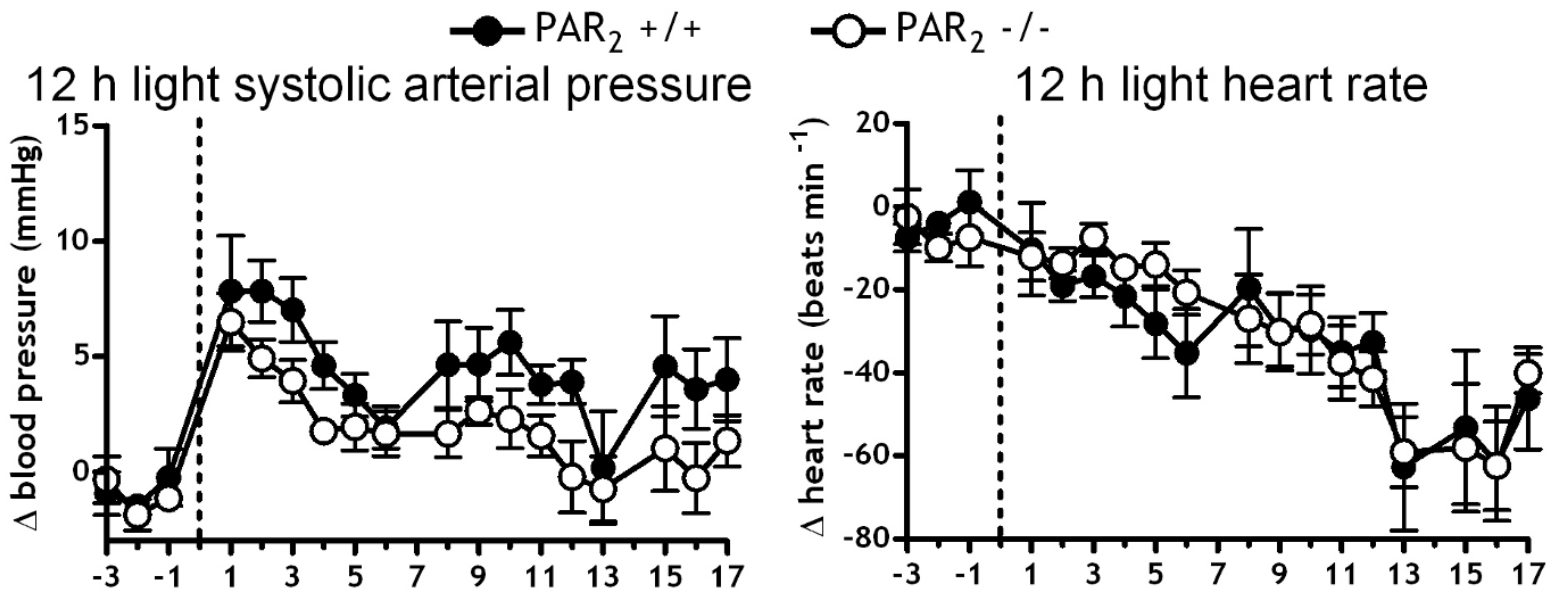

$12 \mathrm{~h}$ light diastolic arterial pressure

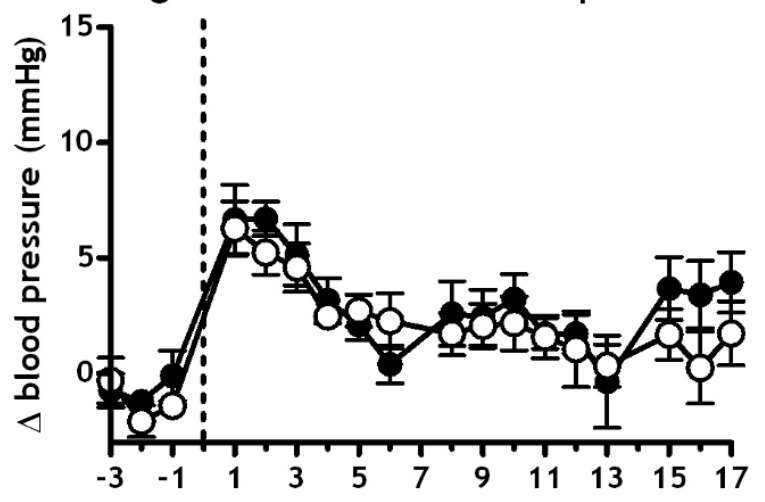

$12 \mathrm{~h}$ light locomotor activity intensity

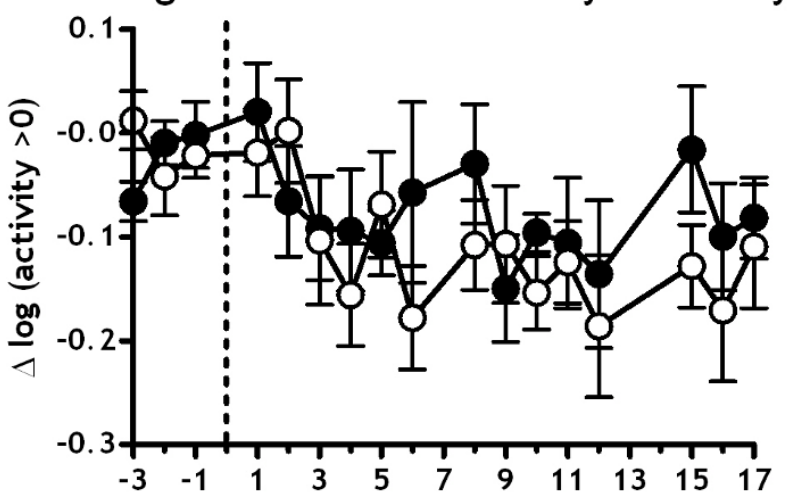

$12 \mathrm{~h}$ light pulse pressure

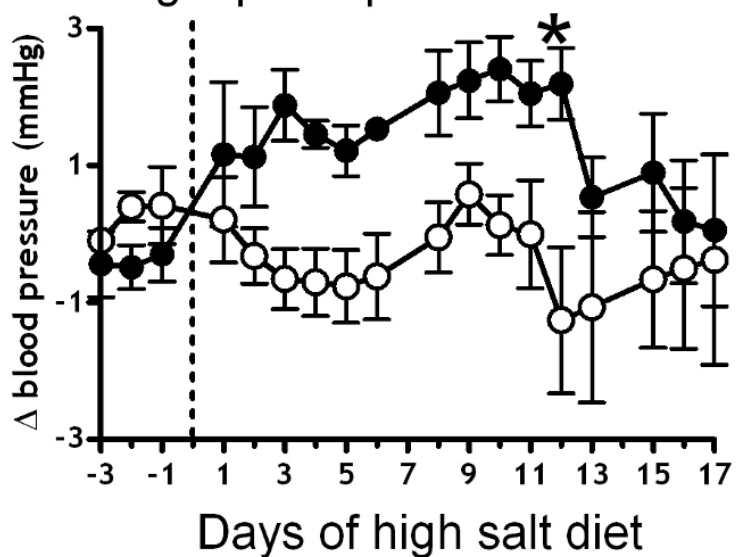

$12 \mathrm{~h}$ light \% time spent active

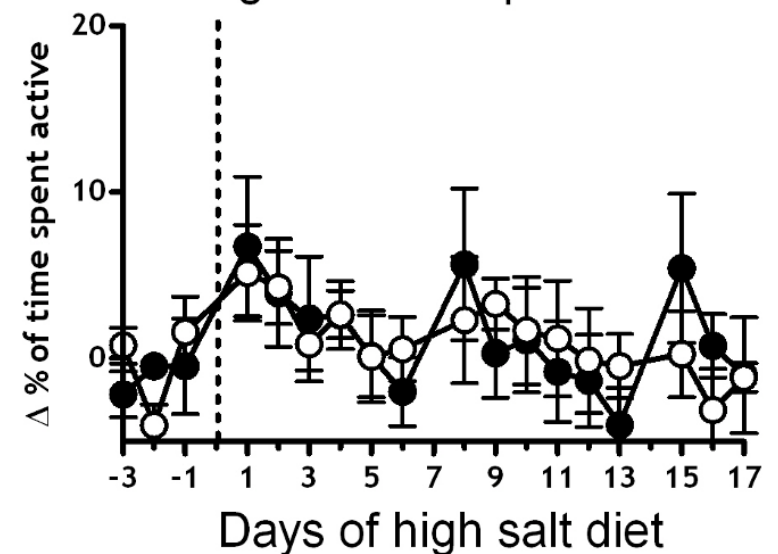

Figure 3

Effect of high salt-diet feeding on $\mathbf{P A R}_{\mathbf{2}}$-/- versus $\mathbf{P A R}_{\mathbf{2}}+/+$ hemodynamics and locomotor activity during $\mathbf{I} \mathbf{~ h}$ light periods. Variables were measured every $30 \mathrm{~s}$ for 18 days via radiotelemetry during a high salt diet $(8 \% \mathrm{NaCl})$ ad libitium. Symbols represent the change in means of variables over the $12 \mathrm{~h}$ light periods relative to baseline feeding with a normal salt $\operatorname{diet}(0.4 \% \mathrm{NaCl}) . \mathrm{n}=5$ in each strain. 2 way repeated measures ANOVA indicated a significant difference $(P<0.05)$ for systolic and pulse pressures between $\mathrm{PAR}_{2}$-/- and $\mathrm{PAR}_{2}+/+* \mathrm{P}<0.05, \mathrm{PAR}_{2}$-/- Ang II compared to PAR 2 +/+ Ang II, 2 way ANOVA and Bonferroni post-hoc test. 

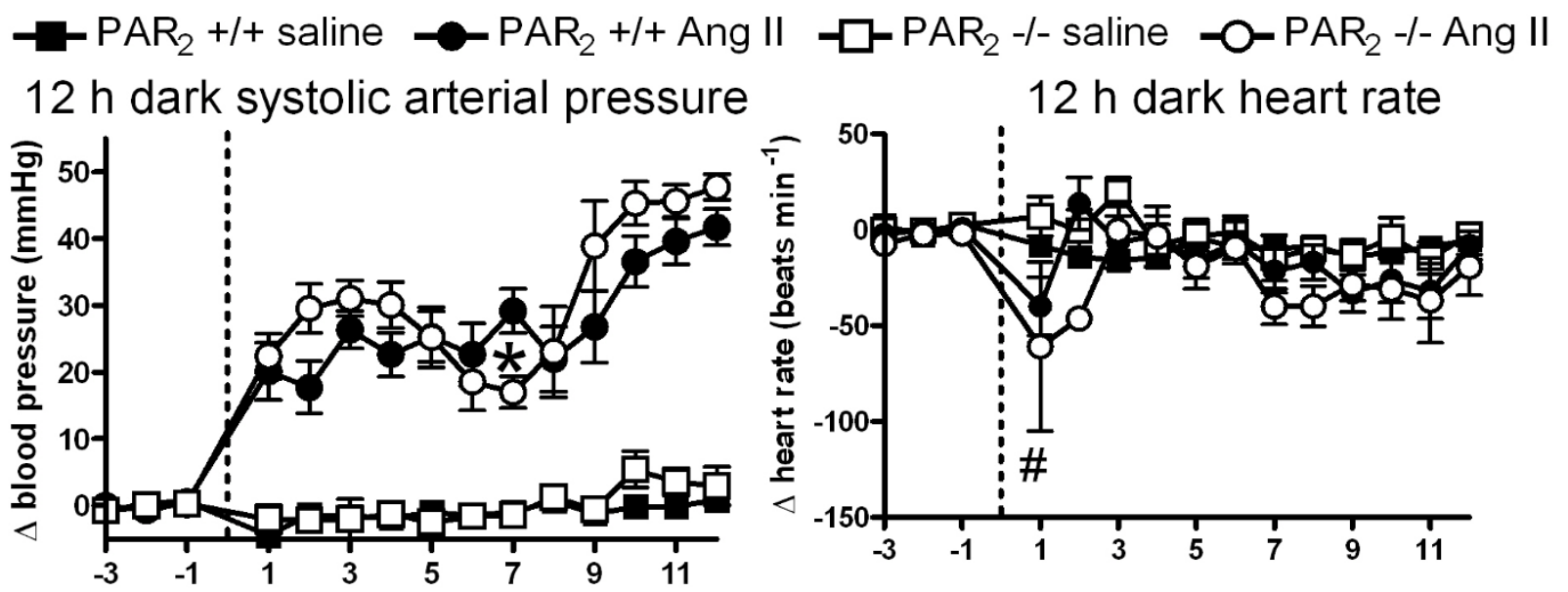

$12 \mathrm{~h}$ dark heart rate

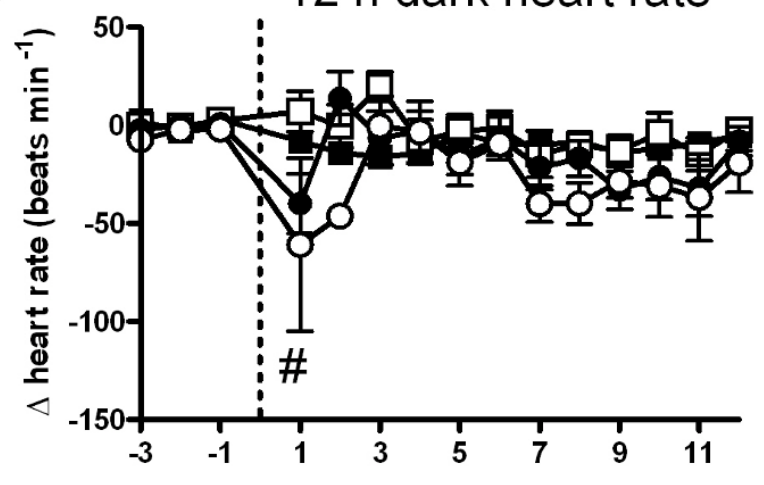

$12 \mathrm{~h}$ dark diastolic arterial pressure

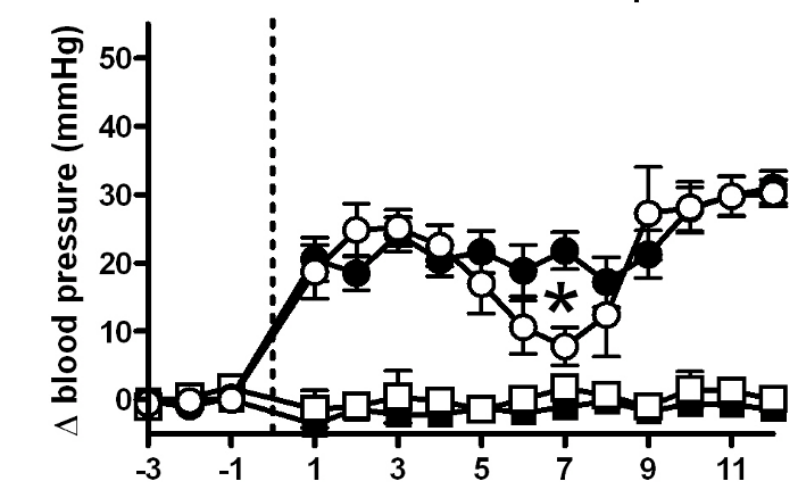

$12 \mathrm{~h}$ dark locomotor activity intensity

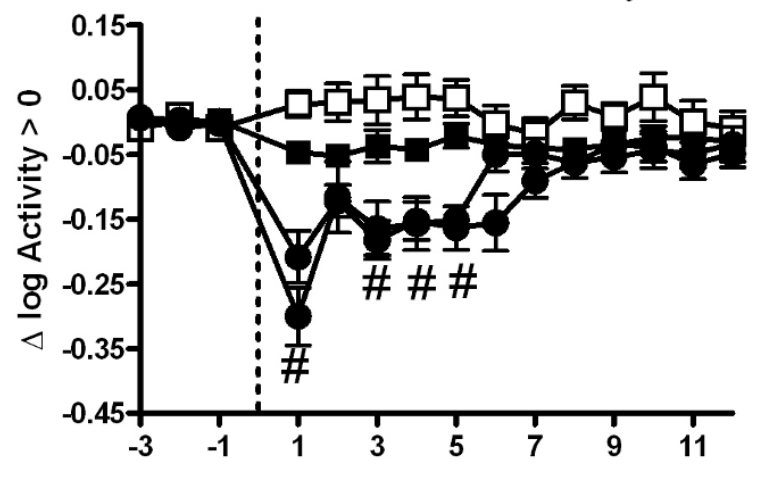

$12 \mathrm{~h}$ dark pulse pressure
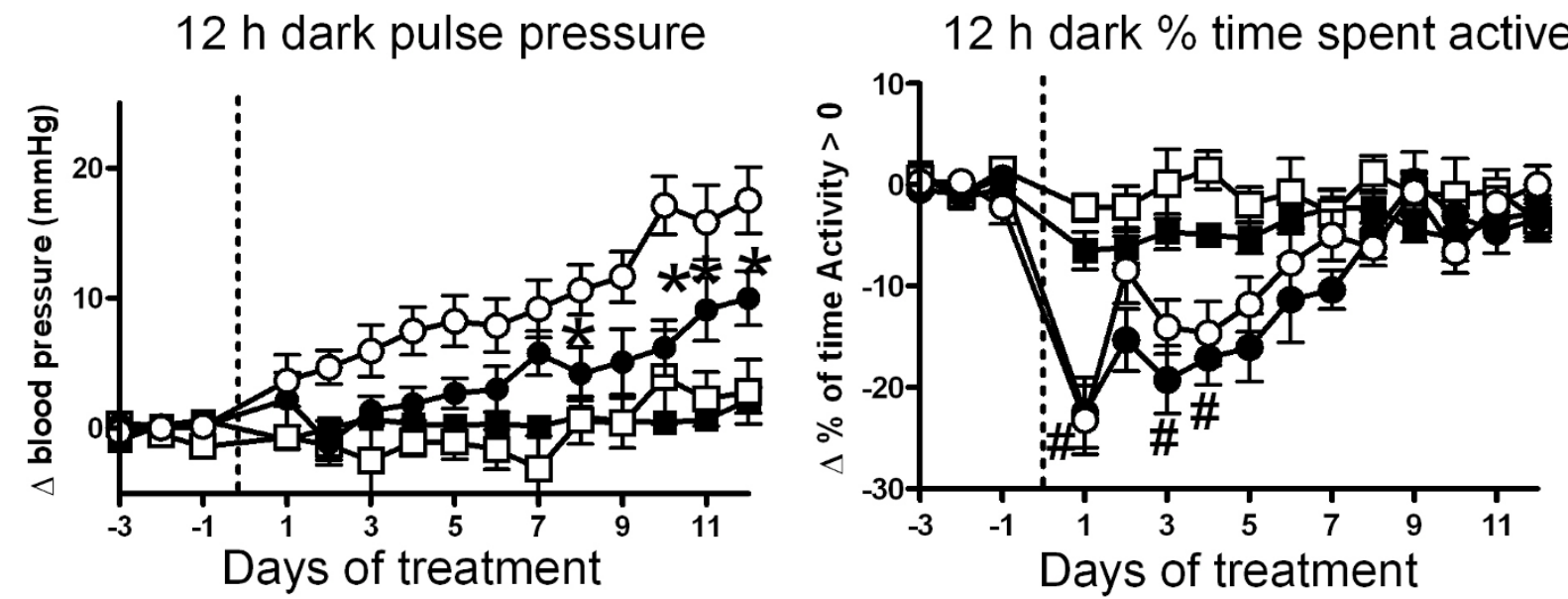

Figure 4

Effect of angiotensin II and saline infusions on PAR - /- versus PAR $_{2}+/+$ hemodynamics and locomotor activity during $\mathbf{I} 2$ h dark periods. Variables were measured every $30 \mathrm{~s}$ for 13 days via radiotelemetry during infusion s.c. with angiotensin II $(\mathrm{I} \mu \mathrm{g} / \mathrm{kg} / \mathrm{min})$ or isotonic saline $(0.5 \mu \mathrm{l} / \mathrm{h})$. Symbols represent the change in means of variables averaged over $12 \mathrm{~h}$ dark periods relative to baseline periods prior to implant of micro-osmotic pumps. Data obtained from 13 PAR $+/+$ saline, I5

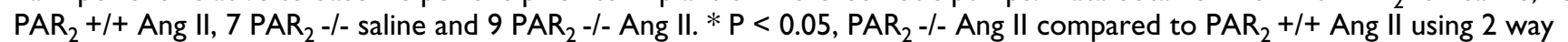
ANOVA and Bonferroni post-hoc. \# $P<0.05$, Ang II-treated $P A R_{2}+/+$ and $P A R_{2}-/$ - versus saline-treated groups, 2 way ANOVA and Bonferroni post-hoc test. 

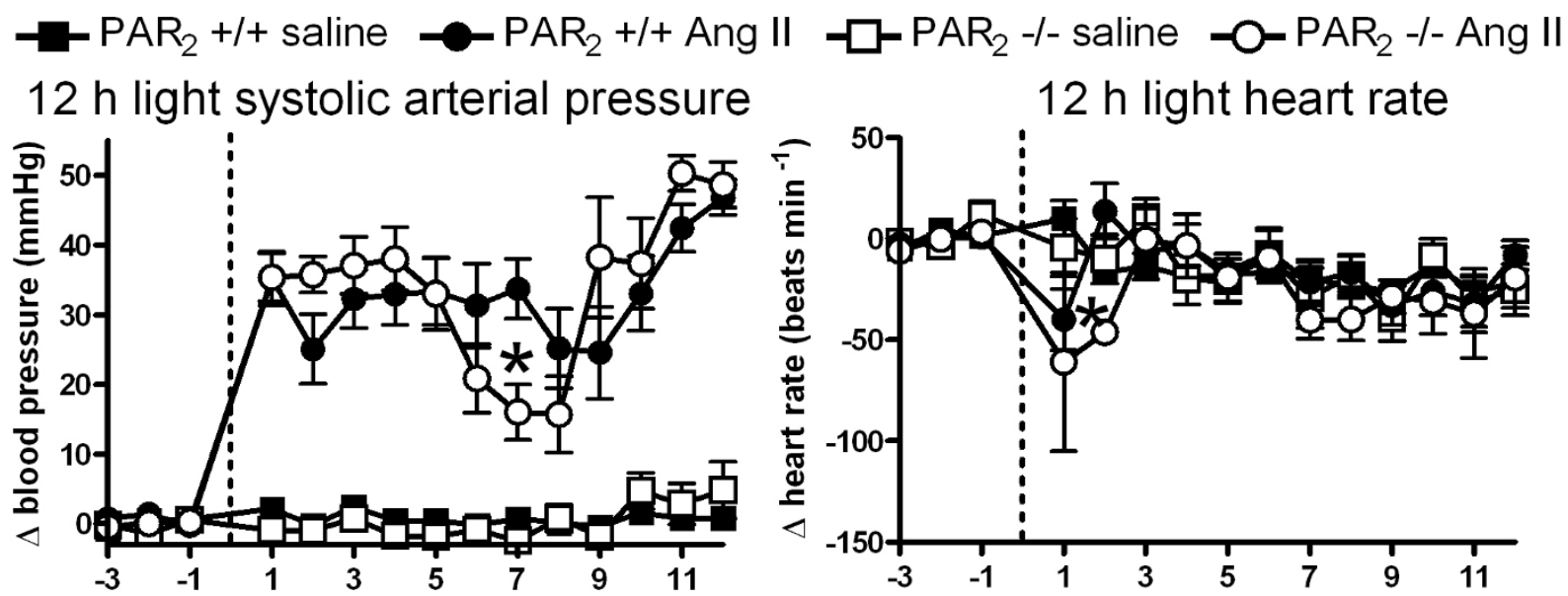

$12 \mathrm{~h}$ light diastolic arterial pressure

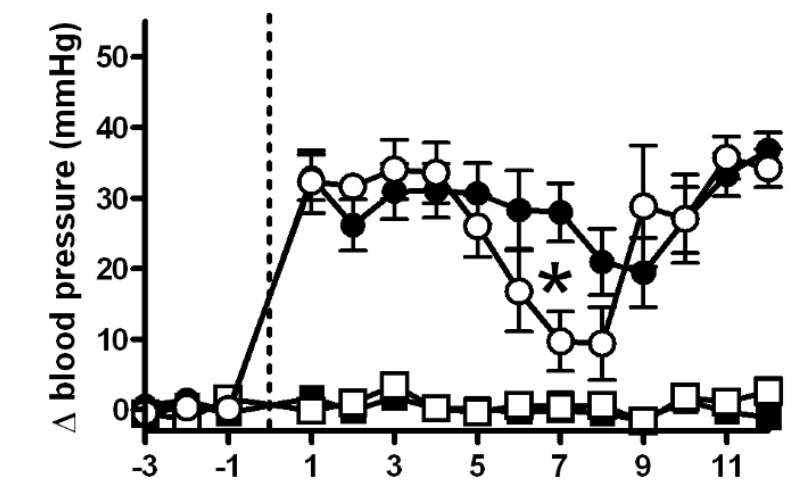

$12 \mathrm{~h}$ light locomotor activity intensity

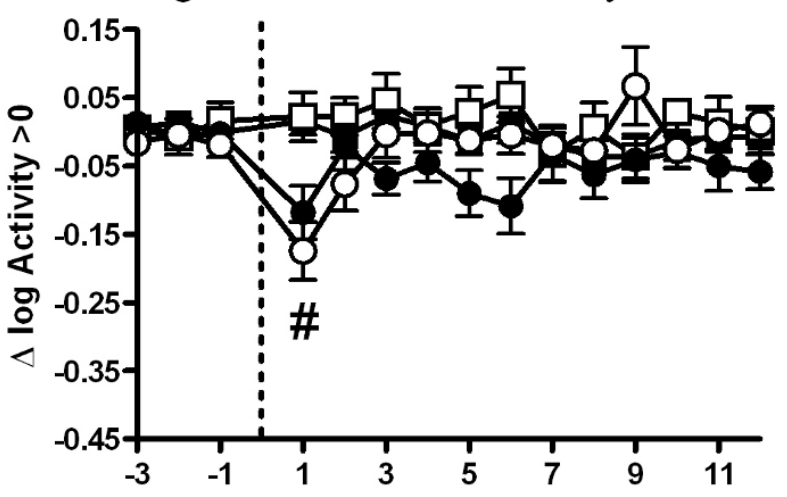

$12 \mathrm{~h}$ light pulse pressure

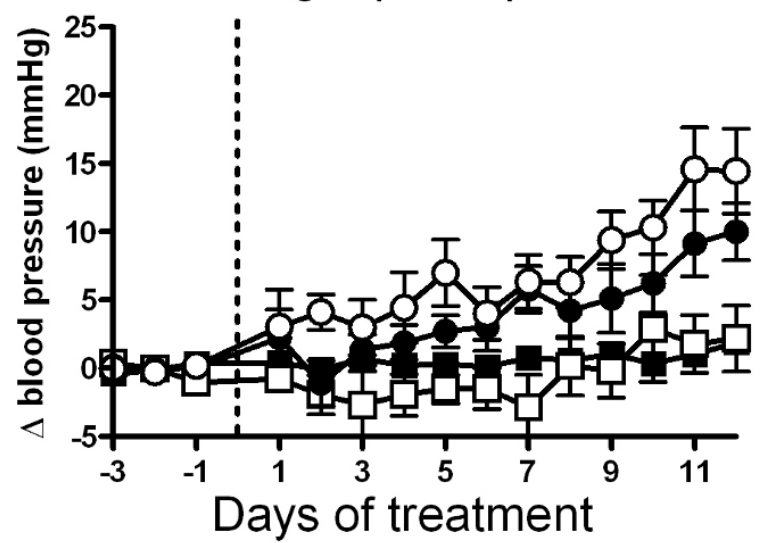

$12 \mathrm{~h}$ light \% time spent active

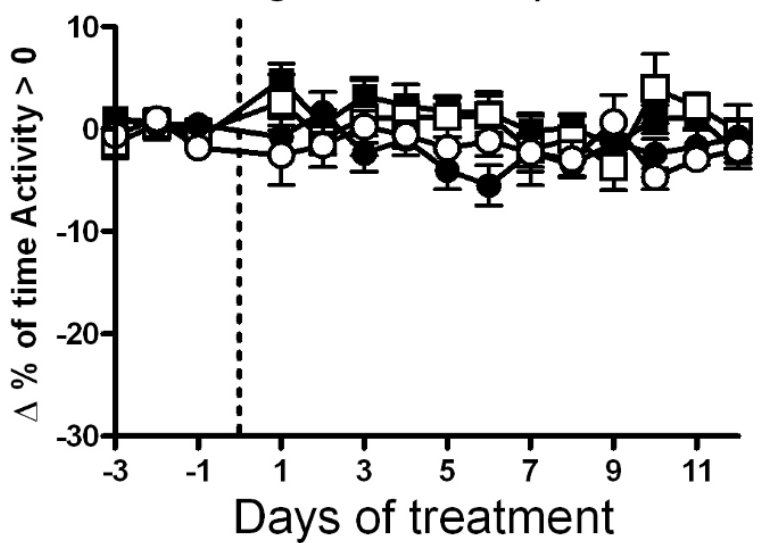

Figure 5

Effects of angiotensin II and saline infusions on PAR $_{2}-/-$ versus PAR $_{2}+/+$ hemodynamics and locomotor activity during $\mathbf{I} \mathbf{~ h}$ light periods. Variables were measured every $30 \mathrm{~s}$ for 13 days via radiotelemetry during infusion s.c. with angiotensin II $(\mathrm{I} \mu \mathrm{g} / \mathrm{kg} / \mathrm{min})$ or isotonic saline $(0.5 \mu \mathrm{l} / \mathrm{h})$. Symbols represent the change in means of variables averaged over I $2 \mathrm{~h}$ light periods relative to baseline periods prior to implant of micro-osmotic pumps. Data obtained from I 3 PAR $2+/+$ saline, I 5

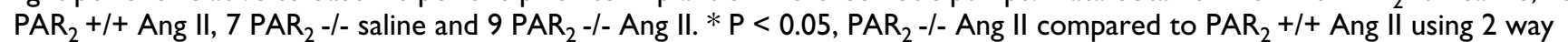
ANOVA and Bonferroni post-hoc. \# $P<0.05$, Ang II-treated $P A R_{2}+/+$ and $P A R_{2}-/$ - versus saline-treated groups, 2 way ANOVA and Bonferroni post-hoc test. 
catheter recordings under anaesthesia [4]. Using a radiotelemetry approach for blood pressure phenotyping in conscious unrestrained $\mathrm{PAR}_{2}$-/- mice, we resolved a very small difference in hemodynamic variables. The magnitude of these differences were so small that the physiological impact may at first glance be considered inconsequential under baseline conditions and further dissection of its nature would appear to be unfeasible. Nevertheless the use of telemetry methodology allows us to conclude with a high degree of confidence that these subtle differences are in fact real effects of $\mathrm{PAR}_{2}-/-$, being observed consistently in freely behaving conscious mice without the limitations that may be imposed by other methods (e.g. anesthetics, restraint, tail warming). Telemetry has been shown to be the most accurate of current techniques available for assessing BP in rodents and has received recommendation as the gold standard method for quantifying the BP phenotype in experimental animals [34]. We also made use of an advantage of radiotelemetrically acquired data to assess interactions between independent variables in order to explain the overall physiological phenotype. For example, analyses of the radiotelemetry data has the ability to dissect the indirect influence of genotype on hemodynamic variables that may arise as a consequence of behavioural changes occurring in the gene knockout. Locomotor activity changes resulting from an abnormal behaviour (hyperactivity) can result in changes to the distribution pattern of hemodynamic variables because conscious blood pressure in mice has been shown to be strongly influenced by locomotor activity $[31,32]$. No other method would likely have identified the small, but significant increase in $\mathrm{HR}$ of $\mathrm{PAR}_{2}$-/- while active at night.

We found that $\mathrm{HR}$ in $\mathrm{PAR}_{2}-/$ - were relatively the same as $\mathrm{PAR}_{2}+/+$ except during activity episodes at night. Differences in $\mathrm{HR}$ of $\mathrm{PAR}_{2}-/-$ and $\mathrm{PAR}_{2}+/+$ during activity of the dark period coincided with similarly raised intensity levels of activity in the dark period (Table 2) which is usual for nocturnal animals. The significance of these findings is unknown, but could reflect a subtle effect of $\mathrm{PAR}_{2}-/$ - on autonomic nervous system reactivity or exercise intolerance.

Slightly higher PP in $\mathrm{PAR}_{2}-/$ - than in $\mathrm{PAR}_{2}+/+$ could indicate reduced endothelial-derived vasodilator tone, reduced central arterial compliance resulting from morphological and composition changes of blood vessel walls (e.g. increased wall thickness, reduced internal diameters, collagen deposition) and/or increased cardiac stroke volumes in $\mathrm{PAR}_{2}$-/-. Activation of $\mathrm{PAR}_{2}$ has numerous effects including endothelium-dependent vasodilation [32,3538], so an elevated peripheral resistance in knockouts would be consistent with a subtle role played by $\mathrm{PAR}_{2}$ in modulating vascular tone. Endothelial NO synthase (eNOS) is considered a major modulator of peripheral resistance and the $24 \mathrm{~h}$ mean blood pressures of eNOS -/mice were found to increase by $\sim 15 \%$ relative to controls when measured by radiotelemetry [31]. The BP elevation observed for $\mathrm{PAR}_{2}$-/- mice in the present study amounts to approximately one fourth of this level. Such differences in BP may be reduced by compensations from the time of conception so could explain the small size of effect of $\mathrm{PAR}_{2}$-/- on baseline hemodynamics in mice even if $\mathrm{PAR}_{2}$ was a critical enzyme in blood pressure regulation. Theoretically, the small impact on $\mathrm{BP}$ could also underestimate the role played by $\mathrm{PAR}_{2}$ in modulating peripheral resistance (if cardiac output decreased in knockouts as part of compensation) or regulating local blood flow distribution.

For $\mathrm{PAR}_{2}$ to interact pathophysiologically with blood pressure control during high salt diet loading, there should be enzymes that mediate its activation that are linked to blood pressure regulation. The human kallikreins family of serine proteinases consists of several isoforms that have been found to activate $\mathrm{PAR}_{2}$ [39]. It was reported that renal kallikrein activity decreased in salt-sensitive hypertensive animals and renal excretion of kallikreins was increased by angiotensin II $[20,21,40,41]$. The majority of kallikreins biological actions are mediated through kinins, interaction with thrombin generation and the coagulation-cascade. However, the presence of residual non-kinin effects on blood pressure regulation by renal kallikreins during salt-loading has provided evidence of additional substrates [42]. In the current study we had hypothesized that $\mathrm{PAR}_{2}$ was one such substrate. As a possible contributor to the mechanism of residual blood pressure lowering activity by kallikreins during salt loading, we had expected that $\mathrm{PAR}_{2}$-/- would have been more salt-sensitive relative to controls, but these mice were in fact less salt sensitive than controls. Even so, the impact of such small absolute differences in the salt-sensitivity of $\mathrm{BP}$ between $\mathrm{PAR}_{2}$-/- and $\mathrm{PAR}_{2}+/+$ would likely to be physiologically trivial, and suggests that $\mathrm{PAR}_{2}$ is unlikely to play a significant role in the regulation of salt balance. In both strains HR was lowered during HS diet, an observation that has been reported in humans [43]. The data do not exclude $\mathrm{PAR}_{2}$ interaction with non-blood pressure actions of HS diet that remain to be investigated.

In addition to HS diet, a condition where the renin-Ang II system would be downregulated, we also treated mice with Ang II infusion in order to investigate possible interaction with $\mathrm{PAR}_{2}$ on high Ang II acquired hypertension. At the end of 2 weeks, the effects of Ang II on BP were similar in $\mathrm{PAR}_{2}$-/- and $\mathrm{PAR}_{2}+/+$ mice. Collating the findings of classic physiology studies in multiple model systems, we expect that the immediate effects of elevating Ang II involve central nervous system and sympathetic nervous system activations and increases in peripheral resistance 
that are then followed later by mechanisms involving the resetting of kidney function and remodeling of the vasculature. Increasingly often there have been studies that have sought out links between inflammation and hypertension development involving angiotensin II. Studies to induce inflammatory responses in $\mathrm{PAR}_{2}$-/- have resulted in mixed findings about pathological outcomes and our data support a main finding of a null effect on Ang IIacquired hypertension. Chronic high dose Ang II infusions over the period used in this study were shown to result in production of signs of vascular inflammation and endothelial dysfunction by the end-point, but have not been studied at the early time point ( 7 day) at which we observed consistent differences in the trend for hemodynamic changes of $\mathrm{PAR}_{2}-/-[18,19]$. We did not rule out the possibility that different results might be obtained in females. While a major interaction between Ang II and $\mathrm{PAR}_{2}$ appears inconsequential to $\mathrm{BP}$ in the long term, other pathological effects of high Ang II that arise independent of BP such as endothelial dysfunction or the effects of threshold BP changes by a lower dose of Ang II could be manifested differently in $\mathrm{PAR}_{2}$-/-. Other characteristics of endothelium-dependent inflammatory responses which have been shown to be different have included the time to onset which was delayed in $\mathrm{PAR}_{2}-/-$ [9] and both leukocyte adhesion and neointima formation, which were reduced in $\mathrm{PAR}_{2}-/-[10]$.

In conclusion, $\mathrm{PAR}_{2}-/$ - mice exhibited a BP phenotype which was characterized by modest increases of systolic arterial and pulse pressures. The $\mathrm{BP}$ of $\mathrm{PAR}_{2}$-/- is not more salt-sensitive than that of wild type mice, but differences in the time course of the BP responses to Ang II in $\mathrm{PAR}_{2}$ /- and $\mathrm{PAR}_{2}+/+$ may indicate the presence of a subtle influence of $\mathrm{PAR}_{2}$ on Ang II modulation of BP.

\section{Authors' contributions}

JJM conceived and designed the study, supervised the planning and execution of experiments, acquisition of data, conducted data analysis and prepared the manuscript. SJH carried out the surgical and telemetry protocols and managed data collection. BVV provided guidance to study design, execution of technical protocols, data analyses and preparation of the manuscript. All authors have read and approved the final draft of the manuscript. Granting agencies did not contribute to study design, data collection, analyses, interpretation, manuscript writing or decision to submit the manuscript for publication.

\section{Acknowledgements}

This study was funded by operating and infrastructure grants from the Canadian Institutes of Health Research (Regional Partnership Program, ROP 72465; ROP 88065; New Investigator Award, RSH 78370), the Department of Innovation, Trade and Rural Development, Province of Newfoundland (Industrial Research and Innovation Fund, 0405-017; 0506-
014; 0708-022; 0708-008) and Canada Foundation for Innovation (New Opportunities Fund, 10027) to JJM.

\section{References}

I. Hollenberg MD, Compton S): International Union of Pharmacology. XXVIII. Proteinase-activated receptors. Pharmacol Rev 2002, 54:203-2I7.

2. Macfarlane SR, Seatter MJ, Kanke T, Hunter GD, Plevin R: Proteinase-activated receptors. Pharmacol Rev 200I, 53:245-282.

3. McGuire JJ: Proteinase-activated Receptor 2 (PAR2): a challenging new target for treatment of vascular diseases. Curr Pharm Des 2004, 10:2769-2778.

4. Damiano BP, Cheung WM, Santulli RJ, Fung-Leung WP, Ngo K, Ye $\mathrm{RD}$, et al:: Cardiovascular responses mediated by proteaseactivated receptor-2 (PAR- 2) and thrombin receptor (PARI) are distinguished in mice deficient in PAR-2 or PAR-I. J Pharmacol Exp Ther 1999, 288:67I-678.

5. Ferrell WR, Lockhart JC, Kelso EB, Dunning L, Plevin R, Meek SE, et al.: Essential role for proteinase-activated receptor-2 in arthritis. J Clin Invest 2003, I I I:35-4I.

6. Kelso EB, Lockhart JC, Hembrough T, Dunning L, Plevin R, Hollenberg $M D$, et al.: Therapeutic promise of proteinase-activated receptor-2 antagonism in joint inflammation. J Pharmacol Exp Ther 2006, 3 16:1017-1024.

7. Cenac N, Coelho AM, Nguyen C, Compton S, Andrade-Gordon P, MacNaughton WK, et al.: Induction of intestinal inflammation in mouse by activation of proteinase-activated receptor-2. Am J Pathol 2002, I6 I:1903-1915.

8. Schmidlin F, Amadesi S, Dabbagh K, Lewis DE, Knott P, Bunnett NW, et al.: Protease-activated receptor $\mathbf{2}$ mediates eosinophil infiltration and hyperreactivity in allergic inflammation of the airway. J Immunol 2002, I 69:5315-532I.

9. Lindner JR, Kahn ML, Coughlin SR, Sambrano GR, Schauble E, Bernstein $D$, et al.: Delayed onset of inflammation in protease-activated receptor-2-deficient mice. J Immunol 2000, 165:6504-65I0.

10. Tennant GM, Wadsworth RM, Kennedy S: PAR-2 mediates increased inflammatory cell adhesion and neointima formation following vascular injury in the mouse. Atherosclerosis 2008, 198:57-64.

II. Moussa L, Apostolopoulos J, Davenport P, Tchongue J, Tipping PG: Protease-activated receptor-2 augments experimental crescentic glomerulonephritis. Am J Pathol 2007, I 7 I:800-808.

12. Noorbakhsh F, Vergnolle N, McArthur JC, Silva C, Vodjgani M, Andrade-Gordon $\mathrm{P}$, et al:: Proteinase-activated receptor-2 induction by neuroinflammation prevents neuronal death during HIV infection. J Immunol 2005, I 74:7320-7329.

13. Noorbakhsh F, Tsutsui S, Vergnolle N, Boven LA, Shariat N, Vodjgani $M$, et al.: Proteinase-activated receptor 2 modulates neuroinflammation in experimental autoimmune encephalomyelitis and multiple sclerosis. J Exp Med 2006, 203:425-435.

14. Jin G, Hayashi T, Kawagoe J, Takizawa T, Nagata T, Nagano I, et al.: Deficiency of PAR-2 gene increases acute focal ischemic brain injury. J Cereb Blood Flow Metab 2005, 25(3):302-3I3.

15. Camerer E, Cornelissen I, Kataoka H, Duong DN, Zheng YW, Coughlin SR: Roles of protease-activated receptors in a mouse model of endotoxemia. Blood 2006, 107:3912-3921.

16. Sevastos J, Kennedy SE, Davis DR, Sam M, Peake PW, Charlesworth JA, et al.: Tissue factor deficiency and PAR-I deficiency are protective against renal ischemia reperfusion injury. Blood 2007, 109:577-583.

17. Leonard AM, Chafe LL, Montani JP, Van Vliet BN: Increased saltsensitivity in endothelial nitric oxide synthase-knockout mice. Am J Hypertens 2006, I 9: I 264-1269.

18. Virdis A, Iglarz M, Neves MF, Amiri F, Touyz RM, Rozen R, et al:: Effect of hyperhomocystinemia and hypertension on endothelial function in methylenetetrahydrofolate reductase-deficient mice. Arterioscler Thromb Vasc Biol 2003, 23:1352-1357.

19. De Ciuceis C, Amiri F, Brassard P, Endemann DH, Touyz RM, Schiffrin EL: Reduced vascular remodeling, endothelial dysfunction, and oxidative stress in resistance arteries of angiotensin IIinfused macrophage colony-stimulating factor-deficient mice: evidence for a role in inflammation in angiotensin- 
induced vascular injury. Arterioscler Thromb Vasc Biol 2005, 25:2106-2113

20. Mills IH, Macfarlane NA, Ward PE, Obika LF: The renal kallikreinkinin system and the regulation of salt and water excretion. Fed Proc 1976, 35: I8I-I88.

21. Uehara Y, Hirawa N, Numabe A, Kawabata Y, lkeda T, Gomi T, et al.: Long-term infusion of kallikrein attenuates renal injury in Dahl salt-sensitive rats. Am J Hypertens 1997, 10:83S-88S.

22. Katori M, Majima M: The renal kallikrein-kinin system: its role as a safety valve for excess sodium intake, and its attenuation as a possible etiologic factor in salt-sensitive hypertension. Crit Rev Clin Lab Sci 2003, 40:43-II5.

23. Cleator JH, Zhu WQ, Vaughan DE, Hamm HE: Differential regulation of endothelial exocytosis of P-selectin and von Willebrand factor by protease-activated receptors and CAMP. Blood 2006, 107:2736-2744.

24. Lim SY, Tennant GM, Kennedy S, Wainwright CL, Kane KA: Activation of mouse protease-activated receptor-2 induces lymphocyte adhesion and generation of reactive oxygen species. $\mathrm{Br}$ J Pharmacol 2006, I 49:59|-599.

25. $\mathrm{Li} \mathrm{T}, \mathrm{He} \mathrm{S}$ : Induction of IL-6 release from human $\mathbf{T}$ cells by PAR-I and PAR-2 agonists. Immunol Cell Biol 2006, 84:46I-466.

26. Fukunaga R, Hirano K, Hirano M, Niiro N, Nishimura J, Maehara Y, et al.: Upregulation of proteinase-activated receptors and hypercontractile responses precede development of arterial lesions after balloon injury. Am J Physiol Heart Circ Physiol 2006 291: $\mathrm{H} 2388-\mathrm{H} 2395$.

27. Syeda F, Grosjean J, Houliston RA, Keogh RJ, Carter TD, Paleolog E, et al:: Cyclooxygenase-2 induction and prostacyclin release by protease-activated receptors in endothelial cells require cooperation between mitogen-activated protein kinase and NF-kappaB pathways. J Biol Chem 2006, 28 I: I I792-I I 804.

28. Luo W, Wang Y, Hanck T, Stricker R, Reiser G: Jab I, a novel protease-activated receptor-2 (PAR-2)-interacting protein, is involved in PAR-2-induced activation of activator protein-I. J Biol Chem 2006, 28 I:7927-7936.

29. Ritchie E, Saka M, Mackenzie C, Drummond R, Wheeler-Jones C Kanke T, et al.: Cytokine upregulation of proteinase-activatedreceptors 2 and 4 expression mediated by p38 MAP kinase and inhibitory kappa $B$ kinase beta in human endothelial cells. Br J Pharmacol 2007, 1 50:1044-1054.

30. Henke N, Schmidt-Ullrich R, Dechend R, Park JK, Oadri F, Wellner $M$, et al: Vascular endothelial cell-specific NF-kappaB suppression attenuates hypertension-induced renal damage. Circ Res 2007, 101:268-276.

3I. Van Vliet BN, Chafe LL, Montani JP: Characteristics of $24 \mathrm{~h}$ telemetered blood pressure in eNOS-knockout and C57BI/6J control mice. I Physiol 2003, 549:3 I3-325.

32. McGuire JJ, Van Vliet BN, Gimenez J, King JC, Halfyard SJ: Persistence of PAR-2 vasodilation despite endothelial dysfunction in BPH/2 hypertensive mice. Pflugers Arch 2007, 454:535-543.

33. Van Vliet BN, McGuire JJ, Chafe L, Leonard A, Joshi A, Montani JP: Phenotyping the level of mouse blood pressure by telemetry. Clin Exp Pharmacol Physiol 2006, 33:1007-1015.

34. Kurtz TW, Griffin KA, Bidani AK, Davisson RL, Hall JE: Recommendations for blood pressure measurement in humans and experimental animals. Part 2: Blood pressure measurement in experimental animals: a statement for professionals from the subcommittee of professional and public education of the American Heart Association council on high blood pressure research. Hypertension 2005, 45:299-3I0.

35. Smeda JS, McGuire JJ: Effects of Poststroke Losartan Versus Captopril Treatment on Myogenic and Endothelial Function in the Cerebrovasculature of SHRsp. Stroke 2007 38: $1590-1596$

36. McGuire JJ, Hollenberg MD, Bennett BM, Triggle CR: Hyperpolarization of murine small caliber mesenteric arteries by activation of endothelial proteinase-activated receptor 2 . Can J Physiol Pharmacol 2004, 82: I 03-IIII2.

37. McGuire IJ, Hollenberg MD, Andrade-Gordon P, Triggle CR: Multiple mechanisms of vascular smooth muscle relaxation by the activation of proteinase-activated receptor 2 in mouse mesenteric arterioles. Br J Pharmacol 2002, 135:155-169.

38. McGuire JJ, Dai J, Andrade-Gordon P, Triggle CR, Hollenberg MD: Proteinase-activated receptor-2 (PAR2): vascular effects of a
PAR2-derived activating peptide via a receptor different than PAR2. J Pharmacol Exp Ther 2002, 303:985-992.

39. Oikonomopoulou K, Hansen KK, Saifeddine M, Vergnolle N, Tea I, Blaber $M$, et al: Kallikrein-mediated cell signalling: targeting proteinase-activated receptors (PARs). Biol Chem 2006, 387:8I7-824.

40. Ardiles LG, Figueroa CD, Mezzano SA: Renal kallikrein-kinin system damage and salt sensitivity: insights from experimental models. Kidney Int Suppl 2003:S2-S8.

41. Katori M, Majima M: A missing link between a high salt intake and blood pressure increase. J Pharmacol Sci 2006, 100:370-390.

42. Yosipiv IV, Dipp S, El-Dahr SS: Targeted disruption of the bradykinin $B(2)$ receptor gene in mice alters the ontogeny of the renin-angiotensin system. Am J Physiol Renal Physiol 200I, 28 I:F795-F80I.

43. Folkow B, Ely D: Importance of the blood pressure-heart rate relationship. Blood Press 1998, 7:133-138.

Publish with Biomed Central and every scientist can read your work free of charge

"BioMed Central will be the most significant development for disseminating the results of biomedical research in our lifetime. "

Sir Paul Nurse, Cancer Research UK

Your research papers will be:

- available free of charge to the entire biomedical community

- peer reviewed and published immediately upon acceptance

- cited in PubMed and archived on PubMed Central

- yours - you keep the copyright 